\title{
LAPAROSCOPIC MANAGEMENT OF OVARIAN ECTOPIC PREGNANCY: A CASE REPORT AND REVIEW OF THE LITERATURE
}

\author{
Polat DURSUN, Serdar KAYA, Eralp BASER, Gogsen ONALAN, Hulusi B. ZEYNELOGLU
}

Department of Gynecology and Obstetric, Faculty of Medicine, Baskent University, Ankara, Turkey

\begin{abstract}
SUMMARY
A multiparous patient with acute pelvic pain admitted to our hospital. She had a history of irreguler menstruation periods and an intrauterine device (IUD) usage. There was an increase in the serum B-hCG levels. The transvaginal ultrasonographic findings were unilateral adnexial mass and intraabdominal free fluid.

Urgently laparoscopic management was planned. In the operation a haemorrhagic ruptured cystic mass from the right ovary, which was thought to be an ovarian ectopic pregnancy was seen and it was excised. Than we confirmed the diagnosis by the histological examination.

In conclusioni, laparoscopic resection of the ovarian ectopic pregnancy is the most suitable conservative management to protect the surrounding ovarian tissue and the future reproductive functions.
\end{abstract}

Keywords: laparoscopic conservative management, ovarian ectopic pregnancy

Journal of Turkish Society of Obstetrics and Gynecology, (J Turk Soc Obstet Gynecol), 2011; Vol: 8 Issue: 4 Pages: 283- 5

\section{OVARYEN EKTOPIK GEBELIĞİN LAPAROSKOPIK YÖNETIMİ: OLGU SUNUMU VE LITERATÜRÜN GÖZDEN GEÇIRILMESİ}

\section{ÖZET}

Hastanemize adet rötarı ve akut başlangıçlı kasılk ağrısı şikayeti ile bașvuran multipar hastanın transvajinal ultrasonografide (TVUSG) unilateral adneksiyal kistik kitlesi, batın içinde serbest sıvı görünümü ve serum B-hCG yüksekliği mevcuttu. Ektopik gebelik ön tanıst ile laparoskopi uygulandı. Sağ overden kaynaklanan hemorajik, rüptüre kistik kitle, over dokusunun maksimum düzeyde korunması hedeflenerek eksize edildi. Patolojik inceleme ovaryen ektopik gebelik olarak raporlandı. Ovaryen ektopik gebelik olgularında konservatif laparoskopik yaklaşım, gelecekteki reprodüktif fonksiyonların korunması açısından önemlidir.

Anahtar kelimeler: laparoskopik konservatif yönetim, ovaryen ektopik gebelik

Türk Jinekoloji ve Obstetrik Derneği Dergisi, (J Turk Soc Obstet Gynecol), 2011; Cilt: 8 Sayl: 4 Sayfa: 283- 5

\section{INTRODUCTION}

Comprising $1 / 7000$ of all pregnancies and $0.5-3 \%$ of all ectopic pregnancies, the ovarian ectopic pregnancy (OEP) is encountered very rarely $(1-3)$, and establishment of the definitive diagnosis is quite challenging in the preoperative period. Ruptured tubal ectopic pregnancy may be thought of at the first glance upon detection of adnexal masses and hemoperitoneum via imaging modalities, although an ovarian cyst or a ruptured corpus luteum is likely to give the same impression as the formers. Moreover, that may possibly be confused with a bleeding ovarian cyst or corpus luteum during laparoscopy.

According to the criteria specified by Spielberg et al (4), such factors as high blood levels of B-hCG, absence of gestational sac in the TVUSG, absence of chorionic villi in the histological specimens and reversal of BhCG to the normal levels sufficed for the definitive diagnosis of ectopic pregnancy.

In the present case, laparoscopic diagnosis and conservative management of an ectopic pregnancy was aimed to be reported.

Address for Correspondence: Dr. Polat Dursun. Başkent Üniversitesi Tıp Fakültesi, Kadın Hastalıkları ve Doğum Anabilim Dalı, Ankara Phone: + 90 (532) 3845158

e-mail: pdursun@yahoo.com

Received: 25 June 2008, revised: 24 October 2010, accepted: 09 March 2011, online publication: 01 April 2011 


\section{CASE REPORT}

A 36-year-old multiparous female patient with irregular menstrual periods who had suffered for 2 days from pain localized in the right lower abdominal quadrant and suprapubic area was admitted to our clinic. No vaginal bleeding was evident in the patient. The physical examination revealed rebound tenderness, along with cervical tenderness during pelvic examination. There was no palpable adnexal mass. In the past medical history of the patient was IUD use for 3 years, with no previous pelvic inflammatory disease (PID) and another ectopic pregnancy. In the laboratory analysis, B-Hcg level, $\mathrm{Hg}$ level, WBC count were measured to be $3035 \mathrm{mIU} / \mathrm{Ml}$, $10.4 \mathrm{gr} / \mathrm{dl}, 11.600 / \mathrm{mL}$, respectively. An impression of a hyperechogenic and hemorrhagic mass lesion $20 \mathrm{~mm}$ in diameter with a central cystic component was detected in the transvaginal ultrasonographic assessment. An IUD was identified within the endometrial cavity without any evidence of a gestational sac. Moderate accumulation of free intraabdominal fluid was noted. A laparoscopic evaluation was then planned for the patient based on the pre-diagnosis of ectopic pregnancy.

Hemorrhagic fluid of around $1000 \mathrm{ml}$ volume and a ruptured cystic mass $3 \mathrm{~cm}$ in diameter were observed during the laparoscopy. The tubes on both sides and the uterus seemed to be normal. The mass lesion in the right ovary was excised using a needlepoint monopolar cautery, avoiding to inflict any damage on the surrounding ovarian tissue and was sent for further pathological assessment. B-hCG level thereafter showed a marked drop, declining to almost zero. The pathology report obtained indicated an ovarian ectopic pregnancy.

\section{DISCUSSION}

Comprising 1/7000 of all pregnancies and $0.5-3 \%$ of all ectopic pregnancies, the ovarian ectopic pregnancy (OEP) is encountered quite rarely ${ }^{(1-3)}$ with equal incidence in both ovaries ${ }^{(5)}$. Possible to present in a later period than the tubal ectopic pregnancies, the ovarian ectopic pregnancies in their early period have been likely to be confused with a hemorrhagic ovarian cyst, luteinizing cysts or corpus luteum, hence taking misdiagnosis $(1,2,6)$. They are generally subject to rupture at the end of the $1 \mathrm{st}$ trimester ${ }^{(6,7)}$. It is also likely for the suffering patients to lapse into a hemodynamic collapse owing to high vascular nature of the ovaries. Such was reported, albeit rare, in the term cases ${ }^{(6)}$ and the cases in their second trimester ${ }^{(7)}$ in the literature.
The diagnosis of ovarian ectopic pregnancy is quite challenging in the preoperative period. Ruptured tubal ectopic pregnancy may be thought of at the first glance upon detection of adnexal masses and hemoperitoneum via imaging modalities. However, such clinical entities as ruptured ovarian cyst or corpus luteum may also yield similar impression ${ }^{(8)}$. Spielberg ${ }^{(4)}$ specified the following 4 diagnostic criteria: (a) the fallopian tube on the affected side should be intact; (b) the gestational sac should definitely occupy the normal position of the ovary; (c) the sac should be connected to the uterus by means of proper ovarian ligament; (d) the ovarian tissues should be demonstrated in the wall of the sac. Our case met all the Spielberg criteria.

On the basis of such findings, in addition to the aforementioned criteria, as elevated levels of B-hCG, absence of gestational sac in the endometrial cavity during TVUSG; detection of a cystic ovarian structure (OEP focus) in the absence of pathology on both tubes, the histological specimens obtained from which demonstrated chorionic villus formations, followed by reversal of B-hCG to normal level, the diagnosis of ectopic pregnancy is established ${ }^{(6)}$, obviating the need for a further practice of culdocentesis anymore ${ }^{(5)}$. In a study conducted between 1971 and 2000 was reported 133.302 births versus 1281 ectopic pregnancies, 37 of which had been ovarian ectopic pregnancies; 65\%(29/37) IUD use and 89\%(33/37) multiparity $(5)$. Another 10 -year study reported a total of 1679 ectopic pregnancies, 54 of which had been ovarian ectopic pregnancies; $43 \% \% 23 / 54$ ) IUD use and $81 \%(43 / 54)$ multiparity ${ }^{(9)}$.

According to the statistical analysis, implementation of IUD has been associated with $99.5 \%$ and $95 \%$ reductions in intrauterine implantations and tubal implantations, respectively; however, no protective effect has yet to be documented to be exerted on the development of ovarian ectopic pregnancy.

Frequent IUD usage has stood for the sole risk factor for the development of distal ectopic pregnancies, including the ovarian ectopic pregnancies ${ }^{(3,9)}$. Pelvic inflammatory diseases (PID), previous history of pelvic surgery and treatment for infertility ${ }^{(3)}$ have also been considered to be possible predisposing factors ${ }^{(1)}$. The risk factors for tubal pregnancy have been in accordance with the incidence of OEP. OEPs are more commonly composed of the rare cases associated with multiparity and IUD use ${ }^{(5,7)}$. The proposed etiologies, albeit yet to be elucidated(3), can be specified as follows: (i) inhibition of release of the ovum from the ruptured follicle due to the inflammation (PID, perioophoritis, 
endometriosis) or low intrafollicular pressure; (ii) loss of tubal functions( ineffective ciliary movements, peristaltic dysfunction) for idiopathic reasons or secondary to the inflammation; (iii)parthenogenesis; (iv) prostoglandin use ${ }^{(4,5)}$.

Either after fertilization of the ovum within the ovary (1) or after migration and implantation of the fertilized ovum to the ovary, a cascade leading to the development of the ectopic pregnancy is initiated ${ }^{(1,4)}$. Our case was also a multiparous patient, with documented use of IUD, but without previous history of PID, pelvic surgery, treatment for infertility and prostaglandin use. Diagnosis of OEP is challenging and can only be established on the basis of histological examination after surgery. Surgical management has been ranked first in the treatment. While laparotomy and oopherectomy are among the traditional treatment modalities, the laparoscopic wedge resection has been the most appropriate conservative approach today, attempting to provide the surrounding ovarian tissues with the maximum protection $(1,5)$.

Medical treatment is justified as the second option only in the cases of incomplete surgery( ${ }^{(1)}$, persistence of trophoblastic tissue ${ }^{(1)}$ and B-hCG levels $<5000$ $\mathrm{mIU} / \mathrm{mL}^{(10,11)}$. With methotrexate in the first rank, such medications as prostaglandin $\mathrm{F} 2$, prostaglandin $\mathrm{E} 2$, prostaglandin $\mathrm{F} 2 \mathrm{~A}+$ estrogen and prostaglandin $\mathrm{F} 2 \mathrm{a}+$ mifepristone (RU486) were implemented in a small number of cases.

A minimally invasive approach, the conservative treatment is a simple and safe method in OEP cases, carrying benefits, such as less blood loss, more rapid healing course and shorter durations of hospital stay, compared with the laparotomy. Infliction of less damage on the ovarian tissues and development of postoperative adhesions are of pivotal importance for future reproductive functions $(1,2)$. In conclusion, laparoscopy is the gold standard, possessing both diagnostic and treatment- related characteristics, in the management of $\mathrm{OEPS}^{(1,7)}$.

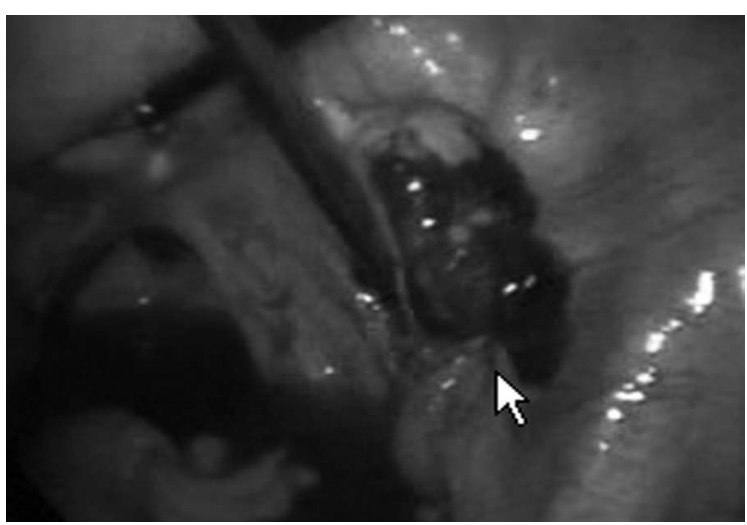

Picture 1: Right ovarian ectopic pregnancy

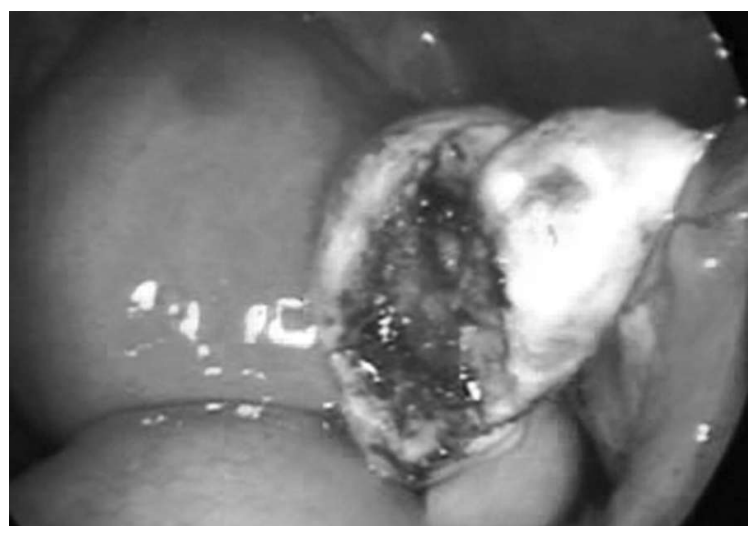

Picture 2: A view after laparoscopic excision

\section{REFERENCES}

1. Atabekoglu CS, Berker B, Dunder I, Case report Ovarian ectopic pregnancy after intracytoplasmic sperm injection, European Journal of Obstetrics \& Gynecology and Reproductive Biology 2004; 112: 104- 6.

2. Guirguis RS, Case Report Laparoscopic treatment of ovarian ectopic pregnancy Gynaecological Endoscopy 2000; 9: 129-31.

3. Dursun P, Gultekin M, Zeyneloglu HB, Case report, Ovarian ectopic pregnancy after ICSI-ET: a case report and literature review, Arch Gynecol Obstet, 2008; 278: 191- 3.

4. Itoh H, Ishihara A, Koita H, Hatakeyama K, Seguchi T, Akiyama Y, Kataoka H, Case Report Ovarian pregnancy: Report of four cases and review of the literature, Pathology International 2003; 53: 806- 9 .

5. Raziel A, Mordechai E, Schachter M, Friedler S, Pansky M, Ron-El R, A Comparison of the Incidence, Presentation, and Management of Ovarian Pregnancies between Two Periods of Time, J Am Assoc Gynecol Laparosc 2004; 11(2): 191- 4.

6. Sehgal A, Goyal LD, Goel P and Suinata BS, Full term ovarian pregnancy: A case report, Australian and New Zealand Journal of Obstetrics and Gynaecology 2005; 45: $165-6$.

7. Kevin J. Corrigan DO, Daniel R. Kowalzyk DO, Case Report, Ectopic ovarian pregnancy in a second-trimester patient American Journal of Emergency Medicine 2007; 25: 1085.e3- 1085.e4.

8. Tan PL, Ridley LJ, Incidental heterotopic pregnancy demonstrated on magnetic resonance imaging, Australasian Radiology 2005; 49: $75-8$.

9. Bouyer J, Coste J, Fernandez H, et al: Sites of ectopic pregnancy: A10 year population-based study of 1800 cases. Hum Reprod 2002: 17: 3224- 30 .

10. Menon S, Colins J, Barnhart KT. Establishing a human chorionic gonadotropin cutoff to guide methotrexate treatment of ectopic pregnancy: a systematic review. Fertil Steril. 2007 Mar; 87(3): 481- 4.

11. Practice Committee of the American Society for Reproductive Medicine, Medical treatment of ectopic pregnancy. Fertil Steril. 2006 Nov; 86(5 Suppl): 96- 102. 